\title{
Contents, Vol. 45, 1984
}

\section{No. 1 Original Paper}

Heart Rate Response to Tilting in Newboms in Quiet and Active Sleep

Finley, J.P.; Hamilton, R.; MacKenzie, M.G 1

Excretory Pattern of Bile during Phototherapy

Berant, ML; Brik, R.; Alon, U.; Makhul, I.; Diamond, E.; Mordochowitz, D

Fetal Ovarian Hilar Cells and Testicular Leydig Cells in Various Complications of Pregnancy

Zondek, L.H.; Zondek, T 17

Pressure Profiles in Neonatal Spontaneously Hypertensive Rats

Gray, S.D 25

Uteroplacental Vascular Perfusion and Blood Flow during Pregnancy in the Guinea Pig

Garris, D.R 33

Triiodothyronine Nuclear Receptors in Liver, Brain and Lung of Neonatal Rats. Effect of

Hypothyroidism and Thyroid Replacement Therapy

Bellabarba, D.; Fortier, S.; Bélisle, S.; Lehoux, J.-G 41

Thyroid Hormone Effects on Skin and Hepatic Epidermal Growth Factor Concentrations in Neonatal and Adult Mice

Hoath, S.B.; Lakshmanan, J,; Fisher, D.A 49

No. 2 Original Paper

The Effect of Hematin on Bilirubin Binding in Bilirubin-Enriched Neonatal Cord Serum

Kirk, J.J.; Ritter, D.A.; Kenny, J.D 53

Brainstem Auditory Evoked Responses in the Newborn Lamb. Studies during Postnatal

Development and Acute Hypoxia

Ashwal, S.; Staddon, T.; Geller, M.; Longo, L.D 58

Cardiovascular and Renal Effects of Isoproterenol Infusions in Young Swine

Buckley, N.M.; Brazeau, P.; Charney, A.N.; Cabili, S.; Feldman, G.; Garvey, M.;

Frasier, I.D 69

Development of Enzymes of Energy Metabolism in Rat Heart

Andres, A.; Satrústegui, J.; Machado, A 78

Glucose Homeostasis in Fasted Neonatal Rats Treated with High Doses of L-Thyroxine

Escrivá, F.; Pascual-Leone, A.M 86

Role of Gastrin and Cholecystokinin in the Ontogenic Development of the Gastrointestinal Tract

Zahavi, I.; Kelly, J.; Gall, D.G

Brief Communication

Serum Angiotensin I-Converting Enzyme Activity in Premature and Full-Term Infants

Maury, M.; Walti, H.; Richer, C; Francoual, C; Relier, J.-P.; Giudicelli, J.-F 102

IV Contents

No. 3 Original Paper

Cardiovascular and Catecholamine Responses to Successive Episodes of Hypoxemia in the 
Fetus

Lewis, A.B.; Wolf, W.J.; Sischo, W 105

Effects of Human Albumin Infusion on Transepidermal Water Loss in Newborn Infants

Hammarlund, K.; Hellsing, K.; Sedin, G.; Strömberg, B 112

Bacterial Endotoxins in Umbilical Cord Blood of Neonates

Scheifele, D.W.; Fussell, S.; Olsen, E 119

Evidence that Hepatic Mitochondrial Mass Decreases during the First Sixteen Hours

following Birth in Starved Newborn Rats

Escrivá, F.; Decaux, J.F.; Ferré, P.; Girard, J.R 125

Developmental Changes in Mitochondrial Components in Liver of Newborn Rats

Miyahara, M,; Kitazoe, Y.; Hiraoka, N.; Takeda, K.; Watanabe, S.; Sasaki, J.; Okimasu,

E.; Osaki, Y.; Yamamoto, H.; Utsumi, K 129

Effect of Fetal Decapitation on the Composition and Metabolic Characteristics of Pig

Skeletal Muscle

MacLarty, J.L.; Campion, D.R.; Hausman, G.J.; Reagan, J.O.; Meredith, F.I

Abstracts

Abstracts from the Meeting of the Neonatal Society. Institute of Child Health, London,

November 3,1983 150

Acknowledgement 155

No. 4 Original Paper

Energy Metabolism and Relative Brain Size in Human Neonates from Single and Multiple

Gestations. An Allometric Study

Hofman, M.A 157

Lecithin-Cholesterol Acyltransferase Activity in Children in the Early Neonatal Period

Dobiásová, M.; Stozický, F.; Kopecká, J 165

Contribution of Heart Muscle, Liver, Skeletal Muscle and Placenta to the Asphyxial Hypo-

xanthine Elevation in the Acutely Exteriorised Fetal Lamb

Thiringer, K.; Karlsson, K.; Rosen, K.G.; Kjellmer, I 169

Fatty Acid Oxidation by Developing Rat Kidney

Freund, N.; Sedraoui, M.; Geloso, J.-P 183

Effects of Dexamethasone Administration to Pregnant Rats on Adenylate Cyclase and Cyclic

AMP Phosphodiesterase Activities in the Maternal and Fetal Lungs

Chaudhary, K.C.; Nijjar, M.S 188

Intestinal Cathepsin B and D Activities of Suckling Rats

Davies, P.H.; Messer, M 197

Effect of Maternal Progesterone Exposure on Fetal Testosterone in Mice

Pointis, G.; Latreille, M.T.; Richard, M.O.; D’Athis, P.; Cedard, L. 203

No. 5 Original Paper

Serum and Urine Amino Acid Patterns during the First Month of Life in Small-for-Date Infants

Robles, R.; Gil, A.; Faus, M.J.; Periago, J.L.; Sánchez-Pozo, A.; Pita, M.L.; Sanchez-

Medina, F 209

Contents V

Plasma Amino Acids of the Mid-Trimester Human Fetus

Mclntosh, N.; Rodeck, C.H.; Heath, R 218

Effect of Phototherapy on Plasma 25(OH)-Vitamin D in Neonates

Gillies, D.R.N.; Hay, A.; Sheltawy, M.J.; Congdon, P.J 225 
Iron Status of the Preterm Infant during the First Year of Life

Halliday, H.L.; Lappin, T.R.J.; McClure, G 228

Perinatal Development of the Lung in Rat and Spiny Mouse: Its Relation to Altricial and

Precocial Timing of Birth

Oosterhuis, W.P.; Mooren, P.G.; Charles, R.; Lamers, W.H 236

The Effects of Myometrial Activity on Fetal Thoracic Dimensions and Uterine Blood How

during Late Gestation in the Sheep

Harding, R.; Poore, E.R 244

Sodium Cholate Interactions with Rabbit's Pulmonary Surfactant

Donoso, P.; Oyarzún, M.J.; Segovia, A.; Guerrero, M.; Puig, F 252

Brief Communication

Differential Stabilities of Fetal Intestinal Disaccharidases Determine Their Relative

Amounts Released into Amniotic Fluid

Potier, M.; Morin, P.-R.; Melançon, S.B.; Dallaire, L 257

No. 6 Original Paper

Human Fetal Weight and Placental Weight Growth Curves. A Mathematical Analysis from a

Population at Sea Level

Bonds, D.R.; Mwape, B.; Kumar, S.; Gabbe, S.G 261

Value of Leukocyte Alkaline Phosphatase and Other Leukocyte Parameters in Diagnosis of Neonatal Infection

Paul, R.S.; Kumar, A 275

Comparison of 2,3-Diphosphoglycerate Metabolism between Fetal and Postnatal Pig Red

Cells

Watts, R.P.; Kim, H.D 280

Development of the Gastrointestinal Mucosal Barrier. IV. The Effect of Inhibition of

Proteolysis on the Uptake of Macromolecules by the Intestine of the Newborn Rabbit before and after Weaning

Udall, J.N.; Bloch, K.J.; Vachino, G.; Feldman, P.; Walker, W.A 289

Brief Communication

Litter Size, Maternal Parameters, and Brain and Body Parameters of Neonatal Rats

Zamenhof, S.; Marthens, E. van 296

Abstracts

Abstracts from the Meeting of the Neonatal Society. Institute of Child Health, London, February 2, $1984 \quad 299$

Erratum 302

Author Index 303

Subject Index 305 